\title{
Descriptive analysis of School Inclusion through Index for Inclusion
}

\author{
Sergio SÁNCHEZ ${ }^{1}$, Henar RODRÍGUEZ ${ }^{2}$ y Marta SANDOVAL ${ }^{1}$ \\ ${ }^{1}$ Interfaculty Department of Evolutionary and Educational Psychology of the Faculty \\ of Teacher Training and Education, Autonomous University of Madrid \\ ${ }^{2}$ Department of Pedagogy, University of Valladolid, Valladolid, Spain
}

(Received on June 07, 2017; Accepted on September 21, 2018)

\begin{abstract}
Aligning the paradigm of inclusive education, the main objective that promoted this study presented below was to evaluate the approach and inclusive measures implemented to 430 education professionals from different centres educational primary school in Spain. The questionnaire assesses the three dimensions that Booth \& Ainscow define inclusive education (Cultures, Policies and Practices). In this study, it is performed a descriptive analysis of the questionnaire to analyse the barriers and facilitators to the implementation of inclusive educational approaches. The type of school (public, rural or private), schools are learning communities, number of teachers, results that analyse the content of the items of the instrument and turn relate the degree of inclusion as contributing variables support, number of pupils with special educational needs, type of school grouping, family involvement, coexistence and expectations.
\end{abstract}

Keywords: Inclusive Education; Index for Inclusion; Inclusive cultures; Inclusive Policies; practices Inclusive School

\section{Análisis descriptivo de la Inclusión Escolar a través del Índice de Inclusión}

RESUMEN: En línea con el paradigma de la educación inclusiva, el principal objetivo que impulsó este estudio que se presenta a continuación fue evaluar el enfoque y las medidas inclusivas aplicadas a 430 profesionales de la educación de diferentes centros educativos de educación primaria en España. El cuestionario evalúa las tres dimensiones que Booth \& Ainscow definen para la educación inclusiva (Culturas, Políticas y Prácticas). En este estudio se realiza un análisis descriptivo del cuestionario para analizar las barreras y los facilitadores a la implementación de los enfoques educativos inclusivos. El tipo de escuela (pública, rural o privada), las escuelas son comunidades de aprendizaje, el número de profesores, resultados que analizan el contenido de los ítems del instrumento y a su vez relacionan el grado de inclusión como variables contribuyentes de apoyo, el número de alumnos con necesidades educativas especiales, el tipo de agrupación escolar, la implicación familiar, la convivencia y las expectativas.

Palabras clave: Educación inclusiva; Índice de inclusión; Culturas inclusivas; Políticas inclusivas; Prácticas Escuela inclusiva 
Correspondencia: Campus Canto Blanco. Facultad de Formación del Profesorado y Educación. CP: 28049. Madrid, Spain. E-mail: sergio.sanchezfuentes@uam.es

\section{Introduction}

A growing challenge for the education of all countries lies in providing a quality education that is "inclusive". In addition to being a fundamental human right, it is the foundation for achieving social cohesion (UNESCO, 2008, 2005). In recent years, the "Inclusive" education has received a boost in many educational systems (Kyriakides, Creemers \& Charalambous, 2018). On the basis of the criticism of the special education inspired by the classification of students by alleged imperfections, as denounced by different institutions (Disability Rights Commission, 2007), the scientific debate has expanded to converge toward the concept of inclusive education or education for all (Echeíta \& Ainscow 2010; Dyson, 2001; Dyson \& Millward, 2000; Ainscow, Farrel \& Tweddle, 2000), occurring from the Salamanca Conference (Echeíta and Verdugo, 2004), a terminological shift which we moved to talk about integration to inclusion, conceptualizing the term from more productive educational approaches, that moved away from theories of deficit, and focused on the effectiveness of inclusive schools for all (Vislie, 2003; Farrel, 2000).

The political agendas of many countries promote reforms aimed at developing more inclusive education systems. In this respect, the Education 2030 initiative represents an important step forward, where the priority is clear: to ensure inclusive and equitable quality education and promote lifelong learning opportunities for all (UNESCO, 2015)

In terms of policy and practice, inclusion has gained ground internationally over the past decades. It has also been subjected to close scrutiny in theoretical discussions, and the meaning of inclusion remains confused and, sometimes, controversial.

Today it can be affirmed that inclusion constitutes a challenge to which the international educational systems have adhered to improve the quality of teaching and the response to the diversity of the students, promoting learning opportunities for all and considering education as an emancipating element that transform lives (UNESCO, 2016). In this line, some research supports the positive influence that the application of measurement instruments has had for the change towards inclusive orientation practices in educational institutions (Amor, et al., 2018).

Therefore, it is necessary to promote reflection on what inclusion means and what actions should be taken to move policies and practice in a more inclusive direction. However, capturing the concept of inclusion as an educational principle and a practical application remains one of the most challenging tasks related to education. (Shyman 2015).

It has also been subjected to close scrutiny in theoretical discussions, and the meaning of inclusion remains confused and, sometimes, controversial (Verdugo \& Rodríguez, 2012)

The Index for Inclusion is an example of a developmental, self-evaluation tool (Booth \& Ainscow, 2016; Booth, Simón, Sandoval, Echeíta \& Muñoz, 2015) which has been designed specifically to support and assist with the process of developing inclusive education. It can be (c) Psy, Soc, \& Educ, 2019, Vol. 11(1) 
modified for local use and adapted to meet the needs of individual institutions and is intended to support critical reflection and action through a process of self-review and evaluation.

“The 'Index for inclusion: developing learning and participation in schools' is a set of materials to support the self-review of all aspects of a school, including activities in playgrounds, staff rooms and classrooms the communities and environment around the school. It encourages all staff, parents/carers and children to contribute to an inclusive development plan and put it into practice." (p.9)

The materials are focused on processes and are intended to support the development of a framework for change and action through a whole school/institution approach. The Index for Inclusion is a tool not only created to evaluate inclusive approaches used by the school, but to support the development of the approach in practice. It has been used internationally in several schools, improving inclusive practices and being reflected in the development of policies and documents.

This instrument is based on a theoretical framework of international reference, which includes the following four theoretical areas that interact among themselves: policies, concepts, structures and practices (Ainscow, Booth \& Dyson, 2006). The interaction among these fields determines the effectiveness of inclusive education. In turn, these dimensions are optimized in three relevant school variables: presence, learning and participation. Presence refers to places in which students attend school. The variable Learning includes the measures adopted by school to provide quality experience for all students in order to optimise the performance at school. Finally, the duty to recognise and appreciate the identity of each student and the concern for their personal well-being is specified with Participation (self-esteem, comradeship, absence of exclusion) (Ainscow, et al., 2006).

The Index for Inclusion is structured in three sections. The first section provides an approach to create a language in the centre which allows the understanding and transforming of educational reality. The second section consists of five periods of the process of the Index: opening, analysis, development of a plan for improvement, implementing improvements and process evaluation. The third section presents three large dimensions (create cultures, develop their policies and inclusive practices). In turn, each dimension is divided into two sections and each of them has got 44 indicators. Finally, each indicator consists of ten questions that invite you to reflect and suggest directions for change.

These large sections and specific indicators which help teachers to implement and evaluate their school practice are: DIMENSION A: Creating inclusive cultures: building community and establishing inclusive values; DIMENSION B: Producing inclusive policies for all and producing organisations which support diversity; DIMENSION C: Creating inclusive practices: orchestrating play and learning and mobilising resources. Consecutively, these sections are specified in indicators of the type: obstacles and limitations for learning and participation.

Authors such as Durán et al. (2005) described in a qualitative way some first experiences of the use of the Index in the Spanish State (more specifically, in Madrid, Catalonia and the Basque 
country) and defended its utility to promote processes of change towards more inclusive schools (Echeíta \& Ainscow, 2010: Sandoval, López, Miquel, Giné \& Echeita, 2002). Recently Valencia Autonomous Community has showed interest in the Index distributions in the network of teacher's centres of this Community. This would explain the fact that there have been relatively few initiatives in the last fifteen years that we have discovered that utilise the Index. Although few known school development initiatives have been developed during this fifteen years, many people seem to be interested in the Index: more than 4500 copies of the latest third edition (Booth and Ainscow, 2015), have been sold (in Spain and abroad) by the Spanish editing house (FUHEM), and it is difficult to guess how many have been downloaded from OEI website where it's also allocate free of charge.

This study carries out a descriptive analysis of the questionnaire to analyse the obstacles and facilitators of the sunset up inclusive educational approaches in schools. Specifically, we intend to collect evidence that allows the identification of ideas concerning inclusive education through analysing of the aspects which facilitate and obstruct the launch of inclusive actions in schools. The intention is to answer the question: where are the hurdles and facilitators to carry out inclusive approaches in schools?

\section{Method}

\section{Participants}

In order to analyse inclusive education difficulties, the questionnaire was applied to a wide number of participants, chosen though trivial sampling. Totally, 430 questionnaires were done for a total number of 112 schools from different parts of Spain. The sample was obtained by convenience sampling, as a valid method in educational researches (Salamanca \& MartínCrespo, 2007) In each school, it was applied from a single scale up to a maximum of 19 , so the average of scales per school was 3.02. Most of schools (70\%) were ordinary centres, $12 \%$ were integration schools and $6.5 \%$ were especial schools. More than three quarters were state schools (78.7\%), 18.7\% were charter schools and two were public schools.

As far as context of location is concerned, sampling was distributed in a fair way between urban contexts $(50.2 \%)$ and rural ones $(44.8 \%)$. As it can be observed in Figure 1, most of schools had pupils with all kinds of countries and ethnic groups. For $67.1 \%$ of students Spanish was the only official school language, though in a wide number of schools English and Spanish were spoken $(20.3 \%)$, followed in number by the centres with English and French as official languages $(7.6 \%)$. 


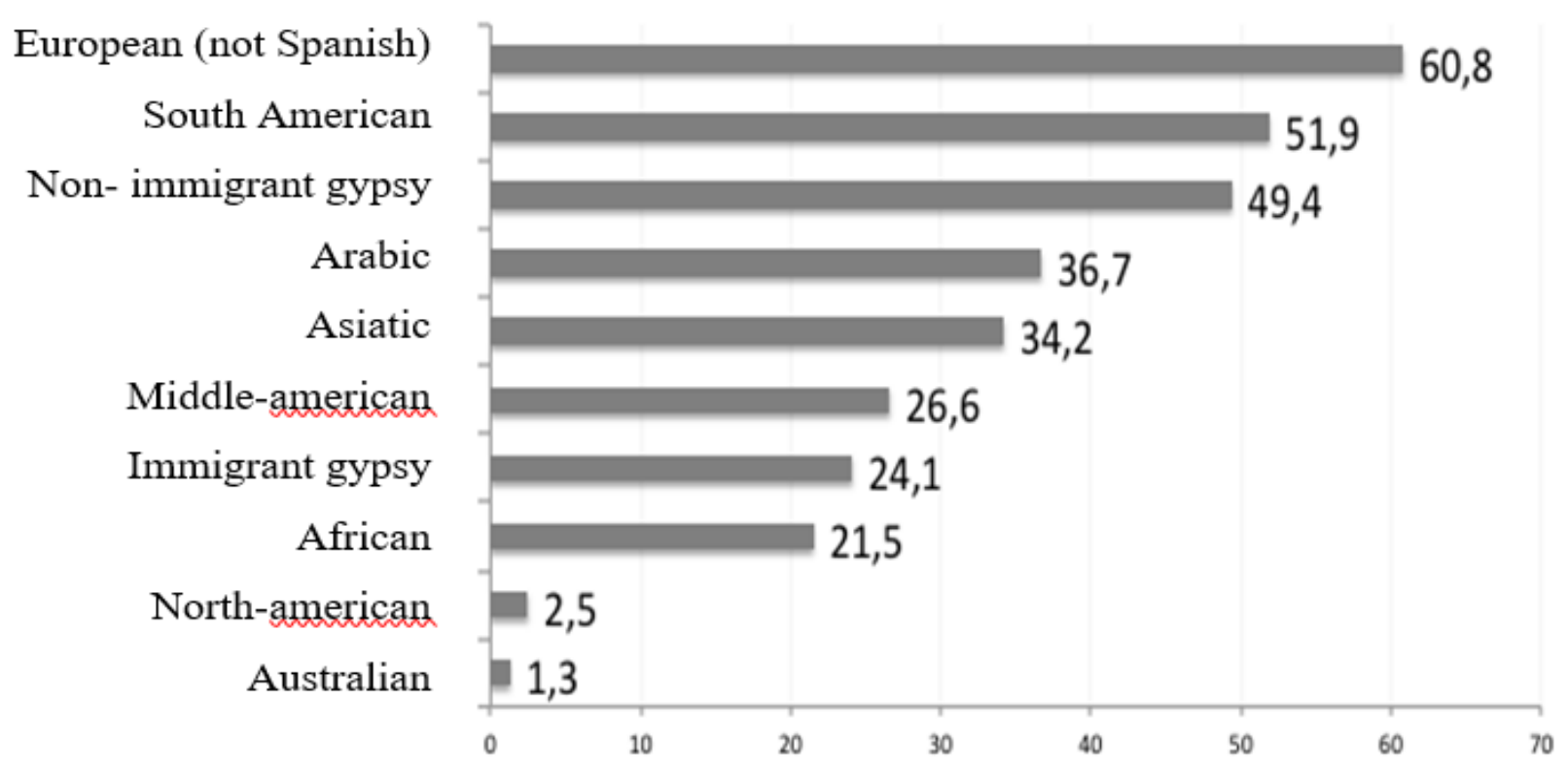

Figure 1. Percentage of centres with students of different backgrounds or ethnic groups

\section{Instrument}

In our case, we have chosen to use an instrument proposed by Booth and Ainscow (2002). It was necessary to translate and adapt to the Spanish context one the questionnaires included in the Index for Inclusion in its third version (Booth \& Ainscow, 2011). As it is known, this instrument was created as an important resource that could help develop more inclusive schools. According to Vaughan (2002) and Bartram (2001), material provided was designed to expand on the knowledge and experience that people have from their schools, to overcome of challenges and thus progress towards more inclusive models, regardless of the degree of inclusiveness of the school at that time. Thus, the Index invites to get rid of obstacles through collecting of information about the culture, policies and practices of schools (i.e., the three dimensions of an inclusive school).

The questionnaire chosen to address the stated objective was Questionnaire 1 of Indicators, consisting of 70 items which are organised around the three above-mentioned dimensions of an inclusive school. The questionnaire had four options to respond (I totally agree=1; I agree =2; I disagree $=3$; I totally disagree $=4$ ).

To position ourselves in this paradigm of inclusive education and to take as a reference the results offered in the project INCLUD-ED (2006-2009) (Flecha, 2010), we aim to assess the focus and inclusive measures of 430 Members that make up the primary education of all Spanish centres. The questionnaire assesses three dimensions which Ainscow and Booth (2011) define inclusive education (cultures, policies and practices) as explained before.

\section{Procedure}

The research group (43 researchers who belonged to different educational fields-university, Primary and Secondary Education, social educators-) previously sent a file to several Nursery 
and Primary schools explaining the research objectives, together with the questionnaire done to 430 members of educational communities from different Primary schools in Spain. They all signed an informed consent on the use of personal data.

They also sent guidelines to complete in relation to the instrument to avoid data lost or confused responses. The results were sent to those centres. Subsequently, a discussion group was conducted with thirteen educators from some centres to deepen the information obtained from the questionnaire analyse in depth the information obtained from the questionnaire. This would be the cell for some faculty who took part in the questionnaire to start a practical work based on these results.

\section{Data analysis}

First, a descriptive analysis of the individual items was carried out in each of the three subscales, estimating the average, standard deviation, asymmetry and curtosis of each item. Next, the internal consistency of each subscale using Cronbach's alpha coefficient was calculated (ordinal form). Several analyses of multiple responses about "special educational needs", "needs of educational compensation", "communities of learning" and "relationship with the centres" were carried out. The totals were calculated by subscale and the overall score, along with the distributional characteristics (averages, standard deviations, asymmetries and kurtosis). Finally, scales from derived typical scores (100 M, of 15) were estimated, both subscales and the total score as well as the corresponding scores centiles. As a complement to previous analysis, several comparisons were accomplished by the type of centre, membership or to learning communities, location of the downtown location (rural or urban area) method of funding, by the number of languages spoken at school, by the type of grouping, by the extent of family involvement, by cohabitation and expectations expressed towards students.

\section{Results}

\section{A. Distribution by dimensions and items}

After having applied The Questionnaire of Indicators of the Index to the described sample previously, - A study was completed in relation to the results obtained according to the dimensions of inclusive education. If we keep in mind that all the items from the questionnaire are formulated in a positive way (e.g., positive valence) and that the scores awarded to each of the four response options, we can conclude that scorings confirmed in schools about inclusive education are high. Then, we will analyse more in detail, assessment results on those items which obtained the best and worst scores.

On the opposite side (e.g., with the best scores in inclusive education), we find five items belonging to the dimension "Creating inclusive cultures" (A.1.1, A.2.2, A.2.7, A.2.8, A.2.3 y A.2.10; most of them belonging to the index "Establishing inclusive values"), three items of the dimension "Originating inclusive policies" (B.1.7, B.1.5 y B.1.6; all of them belonging to the index "Developing one school for all"), and one of the dimension "Inclusive practices 
evolution" (C.2.8, C.2.2, C.2.10 y C.2.11; belonging to the dimension "Orchestrating learning" and C.1.2; belonging to the dimension "Building curricula for all").

So, the item more easily overcome in schools seems to be the one which confirms that "everybody is welcome (A.1.1), for which $97.7 \%$ chooses options "I agree" or "I disagree". Only $2.1 \%$ of the participants states to disagree. In the same way, most of them affirms that school "promotes respect for human rights" (A.2.2; 98.3\%), "it resists to all forms of discrimination" (A.2.7; 97\%), "it promotes interactions and non-violent resolutions of disputes "(A.2.8; 97. 8\%).

Finally, two items stand out among the others, in which the participants mainly claim that the school "promotes the respect for the integrity of the planet" (A.2.3; 96.6\%) and "it contributes to the health of students and adult people/ to students and people's health".

On the other hand, the negative side (e.g., with the worst scores in inclusive education), we find twenty items, either touching or exceeding the point average theoretical scale (2.5). From these, four items belonged to the indicator "Building Community"; A.2.5, belonging to the indicator "Establishing inclusive values"), eight items assessed dimension "Originating inclusive policies" (B.1.2, B.1.3, B.1.10, B.1.11, B.1.12, B.1.13, included in indicator "Developing one school for all"; B.2.2 y B.2.3, of indicator "Organising support for diversity"), and other eight items in the dimension "Evolution of inclusive practices" (C.1.4, C.1.5, C.11, C.1.13, of indicator "Building curricula for all"; C.2.3, C.2.4, C.2.5, C.2.7, of indicator "Orchestrating learning"). It seems, therefore, that the most difficult indicator to achieve in workplaces evaluated is to develop a school for all, and that the greatest difficulties are in organising inclusive public policies and in the evolution of inclusive practices. Then, we offer a more detailed analysis of specific difficulties to which they must face. The three items with which participants showed a greater disagreement were, in first place, those related to have "high expectations of all the pupils" (A.2.5), so that only ten participants affirmed to entirely agree with that assertation and sixty-two claimed to agree (what means that $29.7 \%$ of the aligned participants with this indispensable aspect of inclusive education, while 68.1 acknowledge that they have different expectations for their students).

Second, $35 \%$ of the centres recognised that their "facilities were not accessible physically accessible for all people" (B.1.10), while just 38.6 disagreed with the statement, but not completely.

Third, schools accepted that they had "an inclusive outlook of the leadership" (B.1.2) for more than half of the cases $(60 \%)$, denying it completely or showing moderately disagreement with that assertation in $24 \%$ of the cases.

An $18.6 \%$ of the survey respondents believe that "appointments and promotions are fair", however an (8.5) think that they are not (B.1.3.). In addition, nearly a quarter of the participants think that "buildings and recreational fields do not allow the participation of all" (B.1.11) and "the school does not reduce their carbon impact or use of water" (B.1.12). 14.5\% complains about the fact that "school does not contribute to rubbish reduction" (B.1.13) and "English as 
an additional language is not an available resource for the whole school" (B.2.3). A person out of ten holds that "training activities do not help teachers to pay attention to the diversity of students" (B.2.2.) and that "students do not know details about housing and urban planning" (C.1.4) or "it considers how and why people move around their community and the world" (C.1.5). On the other hand, 16.5\% denies that "assessments motivate the achievements of all the students" (C.2.7), 14.7\% denies that "encourage students to develop critical thinking" (C.2.3), $16.7 \%$ denies that "students are actively involved in their own learning" (C.2.4), that $12.6 \%$ denies that "students learn from each other" (C.2.5). Finally, between 8 and 12 of the respondents shows disagreement with that "students help each other" (A.1.3), adults and the children reply well to different ways of expressing gender" (A.1.9) and "school and local communities contribute to their mutual development" (A.1.10).

\section{B. Relation between inclusive variables}

Subsequently, we compare the degree of inclusion with different variables present in the scientific literature (e.g. type of centre (estate or public), location (urban or rural), schools which are learning communities, number of support teachers, number of students with special educational needs, type of school grouping, family participation, cohabitation and expectations). We observe that a positive relation exists between manifested inclusiveness and some of the studied variables. In order to provide evidence which, guarantee and explain the inclusive theoretical postulates, we will describe each of these comparisons.

Firstly, the sociodemographic characteristics such as the type of centres do not seem to establish significant influence with the inclusion $(F(3)=4.1, p=.007)$. Neither it expresses any kind of relationship, the number of pupils with disabilities and inclusion $(r=.148, p=.006)$. A negative relationship is perceived among the number of support teachers and the inclusive global score $(r=-.28, p=.000)$, that is, the more number of support teachers, the less inclusive global score. However, the type of school grouping (heterogeneous or homogeneous), positively correlates with the degree of inclusion $(F(2)=471.23, p=.000)$. As well as the degree of family participation, the higher it is, the best score in the inclusive scale $(F(2)=377.48$, $p=.000$ ) and cohabitation, the better the cohabitation among members of the educational community, more inclusion $(F(2)=320.22, p=.000)$ and high expectations, being higher the inclusion as better expectations are shown towards the students on behalf of the teachers $(F(3)$ $=68.50, p=.000$ ).

The following figures from 4 to 7 show relations existing between the degree of inclusion and school grouping, family participation, cohabitation and expectations towards students. Figure 8 show the relation between the centres enrolled in an innovative project, the communities of learning and the degree of inclusion in the three dimensions described by literature (CIC, DIP and EIP) Creating Inclusive Cultures, Developing Inclusive Policies and Explaining Inclusive Practices, respectively. 


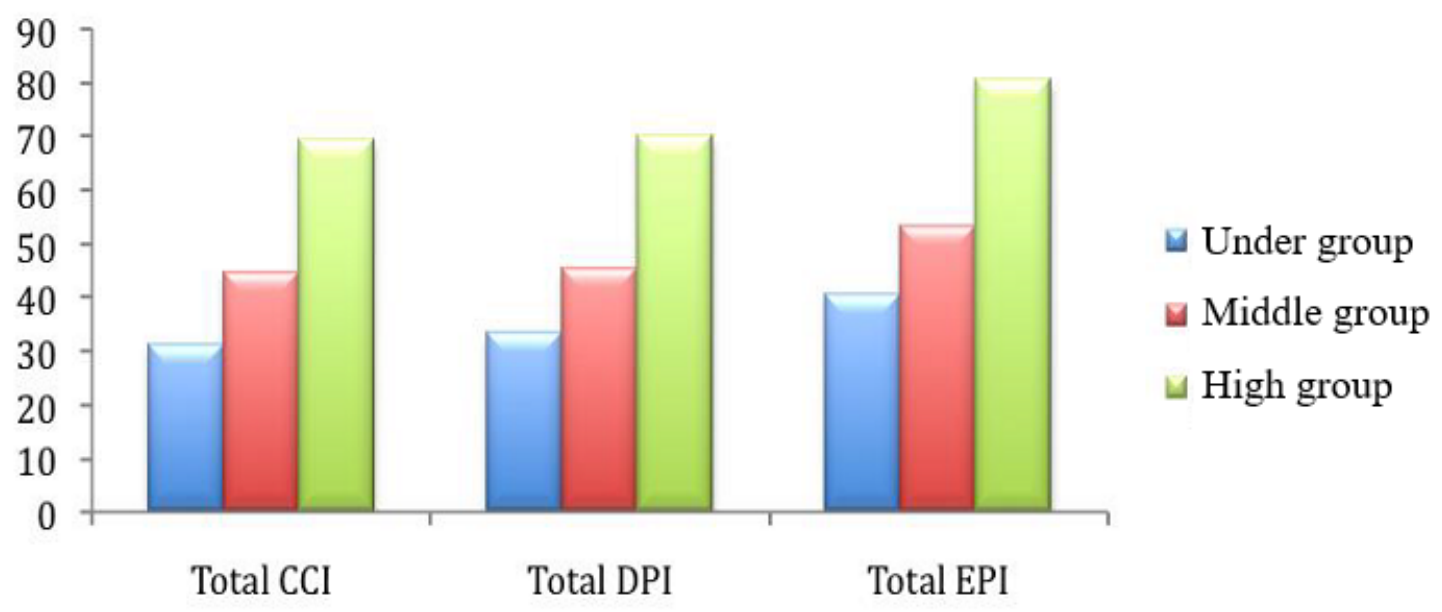

Figure 2. Relation between inclusion and school grouping

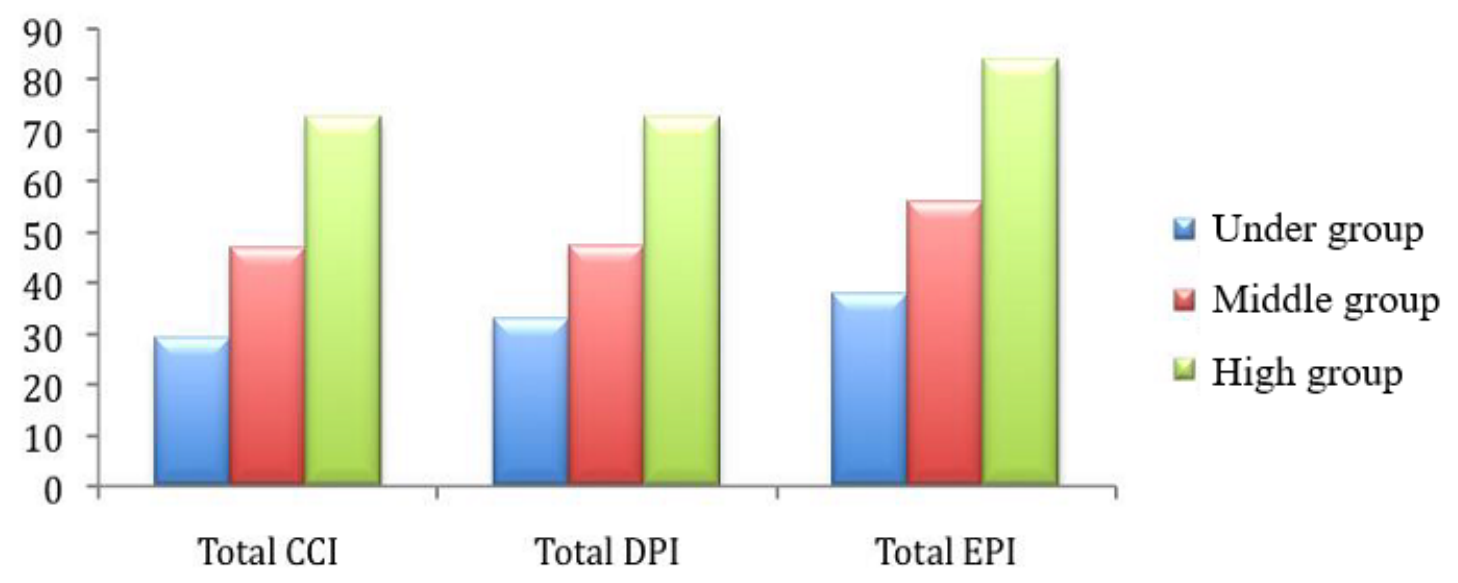

Figure 3. Relation between inclusion and family participation

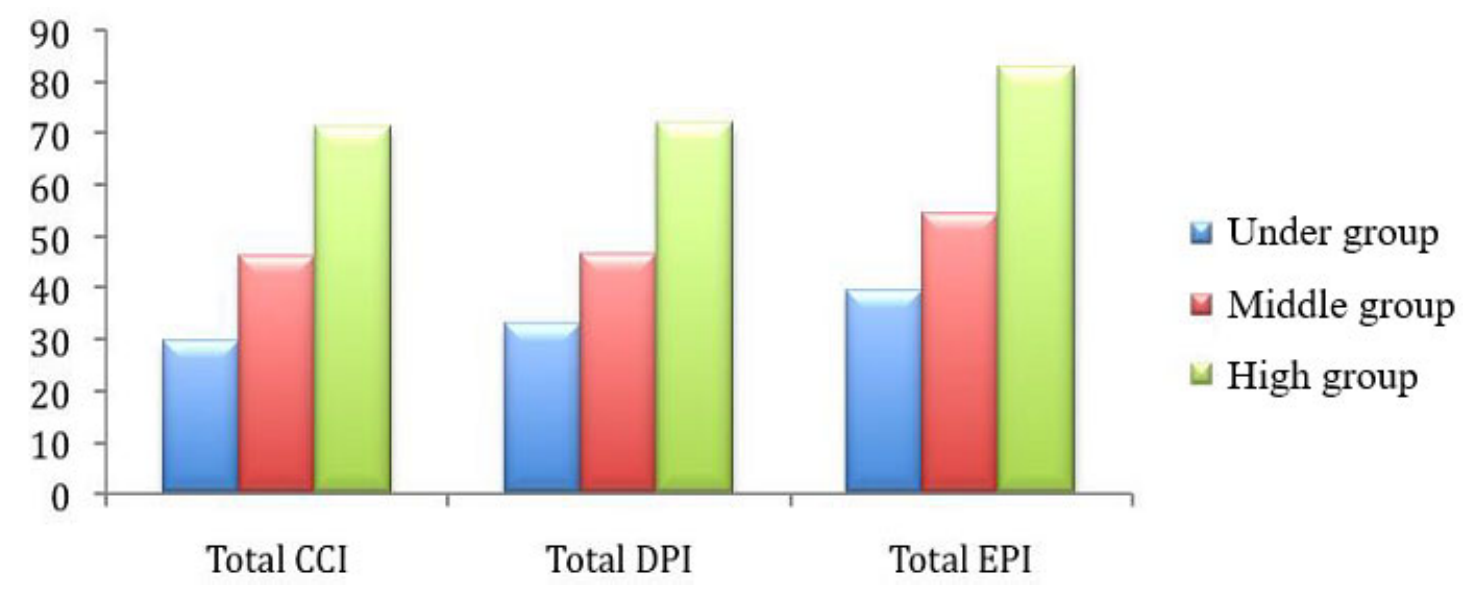

Figure 4. Relation between degree of inclusion and cohabitation 


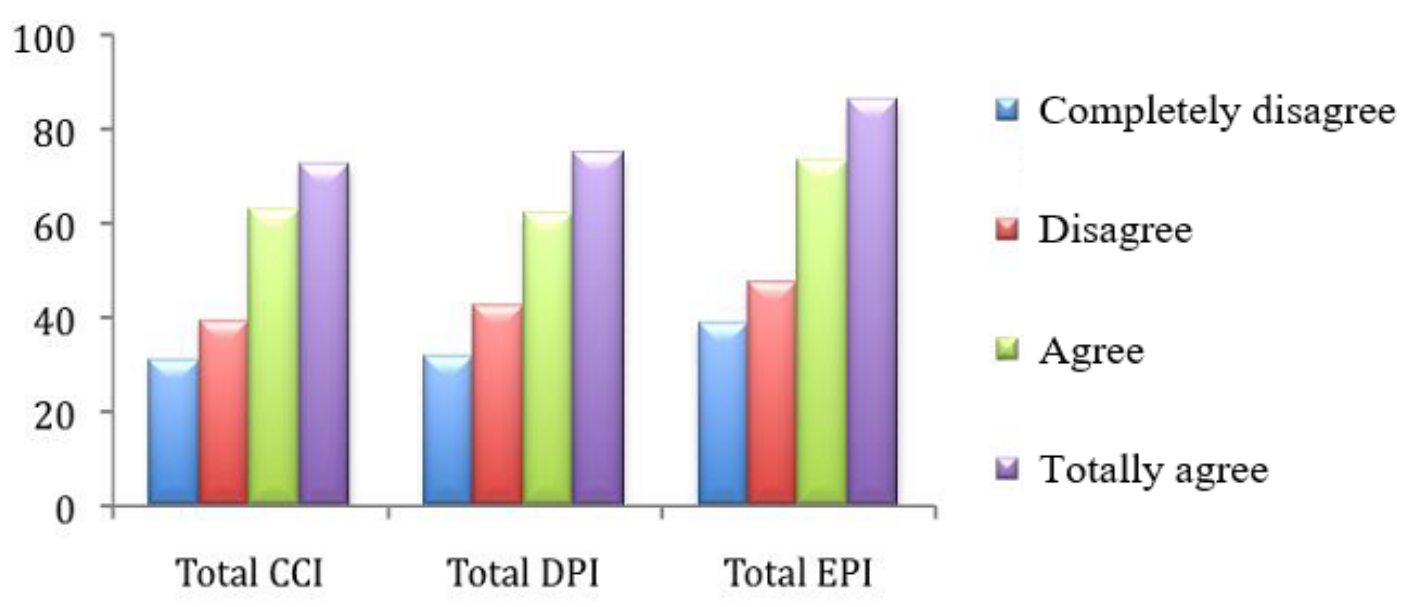

Figure 5. Relation between degree of inclusion and expectations

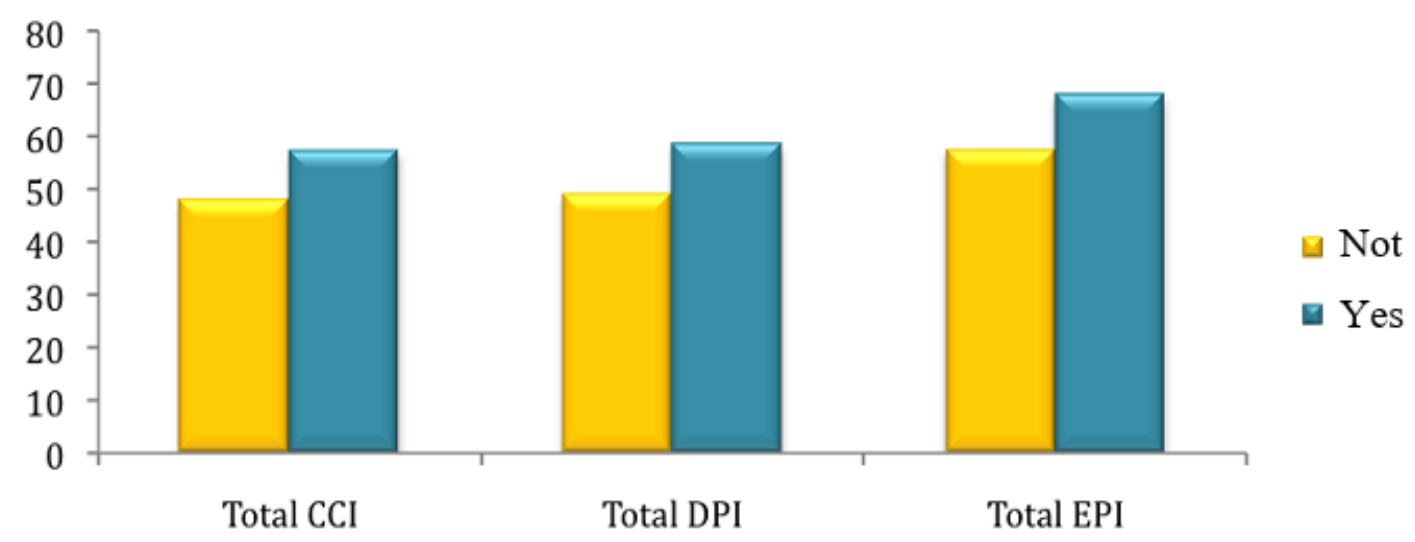

Figure 6. Relation between degree of inclusion and inclusive learning communities

Another interesting result to highlight is referred to educational centres which have any innovation project (i.e. learning communities) to get higher scores in inclusion $(r(414)=2.98$, $p=.003$ ), results which are corroborated by (Includ_ed, 2006-2010). Therefore, we observe that when a group of professionals decides to start a project and all its members direct their effort to reach a common goal, this coming together of educational interests influence the degree of inclusion and, by end, on the quality of the teaching. If we analyse the central/main educational measures which define the centres as learning communities (family training, extra time of learning, organisation of the classroom in interactive groups, volunteering, community participation and dialogic reading), we observe that performance where school centres find more difficult to carry out are: participation of the whole community (7\%), dialogic reading $(13 \%)$ and work with the volunteer (15\%). However, family training $(23 \%)$, the extension of school time (22\%) and the organisation of the classroom in interactive groups $(19 \%)$, are the measures which are mainly put into practice. 


\section{Discussion and Conclusions}

Analysing descriptive results, we can see how the best scored items by educational community (families, teachers, and management team) belong to the following ideas (e.g. High expectations for all the students, Inclusive viewpoint proposed by the management team and Students learning from each other), with what on the one hand, we can think there is certain confidence in school principals, aspect which should ease educational leadership work at schools, with the support and confidence of the rest of the educational community. On the other hand, it has a special value the help among equals in relation to learning in order to improve academic results and school inclusion (Sánchez \& Díez, 2013), as it has been demonstrated by the results offered by the European project (Includ_ed, 2006-2010). At the opposite end, scores with the worst results relate to issues which have traditionally been a barrier to educational quality and inclusion (e.g. Discipline based on mutual respect, Everybody is welcome, Parents, families and teachers collaborate between them and the College promotes respect for human rights.) On the other hand, it is paradoxical how collaboration is perceived as positive among students together and, however, this perception becomes negative when it refers to the relationship between families and teachers. It is very difficult to generate inclusive cultures if collaboration does not suppose a key aspect to the school performance. Likewise, the item "The buildings and recreational fields allow the participation of all", is negatively scored too, with what it can be deduced that educational policies and structures do not leave from school designs with the inclusion or existing school infrastructures have not adapted to these new inclusive paradigms.

The comparative results obtained by this research agree, as we can see, with the suggested proposals by the Project Includ_ed (2006-2010), which identifies a series of educational performances which show inclusive and quality practices such as heterogeneous groupings with reorganisation of resources, the extension of learning time, enhance the interaction between the students, high expectations, the participation of the community in students' learning activities, the participation of families in the decision-making and family training.

There is a vast literature which defends that these are the pillars for the construction of a quality inclusive school (Echeíta, 2008; European Commission, 2005; Driessen, Smit \& Sleegers, 2005; Flecha \& Gómez, 2004).

The very nature of the items formulation shows a contradiction between the expressed perceptions and actions expressed. Therefore, for example, the best scored items (Everybody is welcome to or School promotes respect for human rights) are not items described with an adequate degree of realism and thus, it increases the social desirability, as it also happens with the worse rated item There are high expectations for all students. We need to point out the weakness of the formulation of many items in the questionnaire which question some results and they have been rejected for this research analysis.

Hence, the interest of creating an assessment instrument which meets the adequate psychometric characteristics to evaluate the educational inclusion of Spanish schools which serves as a starting point to contribute to the improvement of school practices. 


\section{References}

Ainscow, M., Farrel, P. \& Tweddle, D. (2000). Developing policies for inclusive Education: a study of the role of local Education authorities. International Journal of Inclusive Education, 4(3), 211-229.

Ainscow, M., Booth, T. \& Dyson, A. (2006). Improving schools, developing inclusion. London: Routledge.

Amor, A., Hagiware, M., Shorgren, K.A., Thompson, J., Verdugo, M.A., Burke, K.M. \& Aguayo, V. (2018). International perspectives and trends in research on inclusive education: a systematic review. International Journal of Inclusive Education, 1-19

Bartram, D. (2001). Guidelines for test users: a review of national and international initiatives. European Journal of Psychological Assessment, 17, 173-186.

Booth, T. \& Ainscow, M. (2002). The Index for Inclusion ( $2^{\text {nd }}$ Ed.). United Kingdom: Centre for Studies on Inclusive Education.

Booth, T. \& Ainscow, M. (2016). Index for Inclusion: developing learning and participation in schools $\left(4^{\text {th }} \mathrm{Ed}\right)$. United Kingdom: Centre for Studies on Inclusive Education.

Booth, T., Simón, C., Sandoval, M., Echeita, G., \& Muñoz, Y. (2015). Guía para la Educación Inclusiva. Promoviendo el Aprendizaje y la Participación enlas Escuelas: Nueva Edición Revisada y Ampliada. REICE. Revista Iberoamericana sobre Calidad, Eficacia y Cambio en Educación, 13(3), 5-19.

Driessen, G., Smit, F. \& Sleegers, P. (2005). Parental Involvement and Educational Achievement. British Educational Research Journal, 31 (4), 509-532.

Disability Rights Commission (2007). Maintaining Standards: Promoting Equality. Retrieved from: http://www.equalityhumanrights.com/uploaded_files/Education/maintaining_stan dards_summary_report.pdf

Durán, D., Echeita, G., Giné, C., Miquel, E., Ruiz, C. \& Sandoval, M. (2005). Primeras experiencias de uso de la Guía para la evaluación y mejora de la educación inclusiva (Index for Inclusion) en el Estado español. Revista Electrónica Iberoamericana sobre Calidad, Eficacia y Cambio en Educación, 3(1). Retrieved from: http://www.ice.deusto.es/RINACE/reice/Vol3n1_e/Duranetal.pdf

Dyson, A. (2001). Dilemas, contradicciones y variedades de la inclusión. In M. A. Verdugo \& B. Jordán de Urríes (Eds.), Apoyos, autodeterminación y calidad de vida (145-160). Salamanca: Amarú.

Dyson, A. \& Millward, A. (2000). School and special needs: Issues of Innovation and Inclusion. London: Paul Chapman.

European Commission (2005). Communication to the spring European council. Working together for growth and Jobs. A new star for the Lisbon Strategy. Brussels: European Commission.

Flecha, R. \& Gómez, J. (2004). Participatory Paradigms: Researching with rather than on. In B. Crossan, J. Gallacher \& M. Osbome (Eds.), Researching Widening Access: Issues and approaches in an international context (pp.129-140). London: Routledge.

Echeíta, G. \& Verdugo, M.A. (Eds.). (2004). La Declaración de Salamanca sobre Necesidades Educativas Especiales diez años después. Valoración y prospectiva, Salamanca:

Publicaciones del INICO. Retrieved from: http://sid.usal.es/idocs/F8/FDO9045/declaracion_salamanca_completo.pdf 
Echeíta, G. (2008). Inclusión y exclusión educativa. "Voz y quebranto". Revista

Electrónica Iberoamericana sobre Calidad, Eficacia y Cambio en Educación, 6(2), 9-18. Retrieved from: http://www.rinace.net/arts/vol6num2/art1.pdf

Echeíta, G. \& Ainscow, M. (2010). La Educación Inclusiva como derecho. Marco de referencia y pautas de acción para el desarrollo de una revolución pendiente. Comunicación presentada en el II Congreso Iberoamericano de Síndrome de Down. Universidad de Granada, Mayo. Retrieved from: http://www.uam.es/personal_pdi/stmaria/sarrio/DOCUMENTOS, \%20ARTICULOS,\%20PONENECIAS,/Educacion\%20inclusiva\%20como\%20derecho.\% 20Ainscow\%20y\%20Echeita.pdf

Farrel, P. (2000). The impact of research on developments in inclusive education. International Journal of Inclusive Education, 4 (2), 153-162.

Flecha, R. (2010). Prácticas educativas que fomentan la inclusión. Conclusiones del Proyecto Includ-ed. In Actas del Simposio Diversidad Cultural y Escuela: El desarrollo de la competencia intercultural.

Kyriakides L., Creemers B., Charalambous E. (2018) Implications for Research, Policy and Practice: A Way Forward. In: Equity and Quality Dimensions in Educational Effectiveness. Policy Implications of Research in Education, vol 8. Springer, Cham

Salamanca, A. \& Martín-Crespo, C. (2007). El muestreo en la investigación cualitativa. Nure Investigación, 27, 1-4.

Sánchez, S., \& Díez, E. (2013). La educación inclusiva desde el currículum: el diseño universal para el aprendizaje. Educación inclusiva, equidad y derecho a la diferencia, 107-119.

Sandoval, M., López, M. L., Miguel, E., Durán, D., Giné, C. \& Echeita, G. (2002). Index for inclusion. Una guía para la evaluación y mejora de la educación inclusiva. Contextos educativos, 5, 227-238.

UNESCO (2015). Education 2030. Incheon Declaration and Framework for Action. Towards Inclusive and Equitable Quality Education and Lifelong Learning for All. Paris: UNESCO

UNESCO (2008). Conferencia Internacional de Educación "la Educación Inclusiva: el Camino hacia el Futuro". Ginebra. Retrieved from: http://www.ibe.unesco.org/fileadmin/user_upload/Policy_Dialogue/48th_ICE/General_P resentation-48CIE-4_Spanish_.pdf

UNESCO (2005). Guidelines for inclusion: Ensuring Access to Education for All. Paris: UNESCO. Retrieved from: http://unesdoc.unesco.org/images/0014/001402/140224e.pdf

Vaughan, M. (2002). An Index for Inclusion. European Journal of Special Needs Education, $17(2), 197-201$.

Verdugo, M.A., \& Rodríguez-Aguilella, A. (2012). La inclusión educativa en España desde la perspectiva de alumnos con discapacidad intelectual, de familias y de profesionales. Revista de Educación, (358), 450-470. https://doi.org/10.4438/1988-592X-RE-2011358-086

Vislie, L. (2003). From integration to inclusion: focusing global trends and changes in the western European societies. European Journal of Special Needs Education, 18(1), 17-35. 